\title{
会話によるニュース記事伝達のための音声合成
}

\section{Speech Synthesis for Conversational News Contents Delivery}

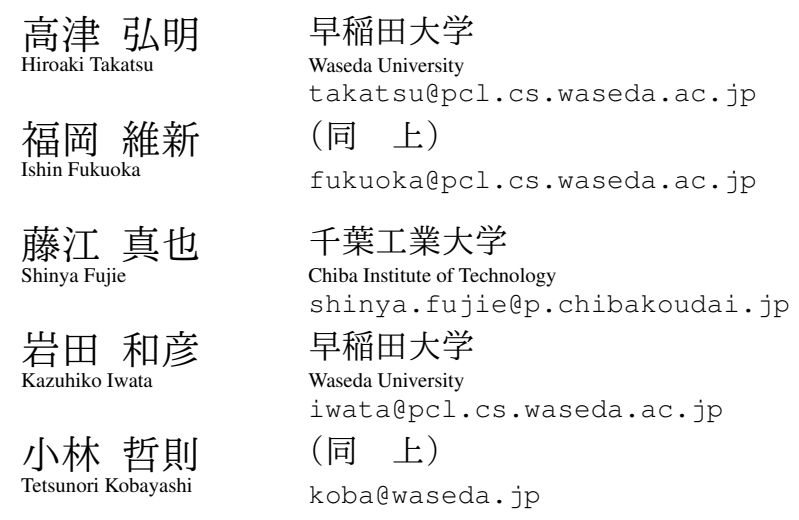

keywords: conversational speech synthesis, DNN-based speech synthesis, paragraph-based speech synthesis, pause length estimation, prominence

\begin{abstract}
Summary
We have been developing a speech-based "news-delivery system", which can transmit news contents via spoken dialogues. In such a system, a speech synthesis sub system that can flexibly adjust the prosodic features in utterances is highly vital: the system should be able to highlight spoken phrases containing noteworthy information in an article; it should also provide properly controlled pauses between utterances to facilitate user's interactive reactions including questions. To achieve these goals, we have decided to incorporate the position of the utterance in the paragraph and the role of the utterance in the discourse structure into the bundle of features for speech synthesis. These features were found to be crucially important in fulfilling the above-mentioned requirements for the spoken utterances by the thorough investigation into the news-telling speech data uttered by a voice actress. Specifically, these features dictate the importance of information carried by spoken phrases, and hence should be effectively utilized in synthesizing prosodically adequate utterances. Based on these investigations, we devised a deep neural network-based speech synthesis model that takes as input the role and position features. In addition, we designed a neural network model that can estimate an adequate pause length between utterances. Experimental results showed that by adding these features to the input, it becomes more proper speech for information delivery. Furthermore, we confirmed that by inserting pauses properly, it becomes easier for users to ask questions during system utterances.
\end{abstract}

\section{1. は じめに}

ニユースのようなまとまった量の情報を伝える会話 システムにおいて，談話構造上の発話の役割に応じた メリハリのある話し方を可能とする音声合成手法を提 案する.

Siri*1や Pepper*2 といった音声対話システムの登場に 伴い, 人とシステムとのインタラクションのあり方が 変化してきている. 古くは, ユーザーの質問に応じて システムが短い回答を提示する質問応答型の対話シス テム [駒谷 03, Seneff 00] が主流であったが, 近年は, 主 体的にまとまった情報を提供する対話システム [Traum

*1 http://www.apple.com/jp/ios/siri/

*2 https://www.softbank.jp/robot/consumer/ products /
15, Yoshino 15] が提案されてきている.

我々も，二ユース記事に代表されるまとまった情報を ユーザーとの会話インタラクションを通じて効率的に 伝達する会話システムの開発を行っている [高津 $18 \mathrm{a}$ ]. このシステムでは，あらかじめ主計画，副計画と呼ぶ 複数のシナリオを用意したうえで，主計画に沿って記 事の要点となる情報を提示する傍らで随時ユーザーか らのフィードバックを理解し, 必要に応じて副計画に 遷移し補足情報を提示する。この機能によって，情報 提示と質疑応答を頻繁に，かつ迅速に切り替えながら 効率的に情報を伝えることができる.

このようなまとまった量の情報を伝える会話システ ムでは，重要な情報がユーザーに伝わる話し方が求め られる. 話し方の教則本などでもよく指摘されている 
ように, 情報を伝える話し方として, 重要な箇所をゆっ くり話して強調する, 相手に理解やフィードバックを 促すように適度に間（ま）を置くなど，メリハリをつけ て話すことが重要である [西野 12,のざき 18].この発 話のメリハリの問題は, 音声合成の分野では, これまで 一文内におけるプロミネンスの付与という形で扱われ てきた [Malisz 17, 武田 91a, 武田 91b]. しかしながら， 発話の強調に影響を与える韻律は, 談話構造に応じて も変化することが古くから指摘されており [Hirschberg 96, 岩田 94, Koiso 97], 一文より長い単位で韻律や間 （ま）を制御する必要がある.

本研究では，このメリハリを実現するために発話の 談話構造上の役割に着目する。音声合成の基盤システ ムとして DNN 音声合成システム Merlin [Wu 16] を採 用したうえで, 談話構造上の文の役割を, 核（最も伝 えたい内容を含む文), 前置き（核を伝えるためのリー ド文), 補足（情報を補足する文）の 3 つに分類し, こ れらを DNN 音声合成の補助情報として利用すること で，発話系列全体で韻律や間（ま）の制御が可能な音 声合成手法を実現する.

本稿では，まず， 2 章で関連研究について述べた後， 3 章で提案システムの構成について説明する. 次に, 4 章で音声合成およびポーズ長（＝間（ま）の長さ）推 定のための音声収録の方法について述べ，収録した音 声の特徵を述べる。そして，5 章で音声合成手法およ びポーズ長推定手法について説明した後, 6 章， 7 章, 8 章, 9 章で提案手法の有効性を評価した結果について 報告する. 最後に, 10 章でまとめと今後の展望につい て述べる。

\section{2. 関 連 研 究}

ニュースの情報伝達に近い分野として, Storytelling を対象とした音声合成の研究がある. Theune らは，人 の語り口調の音声を収集し, 物語において緊張感のあ る場面を語る際の発話の韻律変化に着目し，それを制御 する合成器を開発した [Theune 06]. Montano らは, 語 り口調, 読み上げ, 対話などの発話スタイルや, キャラ クター口調, 緊張感のある状況といった語り口調におけ る調子の異なる音声を収録し韻律の分析とそれを反映 した合成音声の作成を行った [Montano 13]. Sarkar と Verma らは, プロの Storyteller に発話させたヒンディー 語の音声データを収集し, ピッチやテンポ, 強さやポー ズについて分析を行い, ニュートラルな発話スタイル を Storytelling の発話スタイルに変換するルールを定 めた [Sarkar 14, Verma 15]. Ramli らも，マレー語の Storytelling データに関して同様の分析を行い，ニュー トラルな発話スタイルを Storytelling の発話スタイルに 変換するルールを定めた [Ramli 16, Ramli 17].
Storytellingにおけるポーズに焦点を当てた研究も行 われている. Sarkarらは, Storytelling におけるポーズ が物語の緊張感を保つことや, 注目を集める役割を果 たすとして, 決定木を用いたポーズ位置の予測を行った [Sarkar 15a]. また, 後続研究ではポーズのパターンを short, medium, long の 3 種類に分類したうえで, ポー ズ長の予測を行った [Sarkar 15b, Sarkar 15c].

このように物語を対象として, 一文より長い単位で の音声合成の研究は行われているものの, これらは感 情の使い分けや発話スタイルの変換を対象としたもの となっており, 重要な情報を印象付けるようなメリハ リのある話し方を目指したものではない。また，これ らの研究では聞き手とのインタラクティブなやり取り を想定していないため，聞き手が割り込んで発話する のに適した間（ま）の取り方については考慮されてい ない.

会話音声合成のためのデータ収録という観点では, 様々な研究がある。それらは主に実際に会話を行わせ て収録する方法と状況を設定して独話環境で収録する 方法に分類される. 前者の代表例としては, 会話のシ ナリオを用意し，二人の声優に掛け合いをさせて収録 したもの [Sugiura 14] がある. また, 後者の代表的な方 法としては，音声に込めたい感情（例えば「怒り」「喜 び」など）ごとに収録したもの [Adigwe 18, Burkhardt 05], 会話ロボットでの利用場面（例えば「対話を盛り 上げる」「相手を気遣う」など）ごとに収録を行ったも の [Iwata 11] などがある。本研究は，収録の容易性か ら状況を設定して独話環境で収録を行う後者の立場を とるが，従来のような一発話ごとの音声収録ではなく 複数の発話で構成される段落ごとに音声収録を行って いる点, 重要な情報を印象付けるように意識させて発 話させている点, 理解促進や質問誘発のための適度な 間（ま）を入れながら発話させている点など, 情報伝 達を意識させた収録となっている点が異なる。

音声合成手法の観点では, DNN 音声合成モデルの入 力として言語特徵の他に補助的な情報を与えることで 合成音声を制御する試みが行われており，成果をあげ ている。例えば, 入力の補助情報として, 複数話者モデ リングを実現するために話者コードを与える研究 [Hojo 16b, Hojo 18], 話者適応を実現するために i-vector や話 者の性別を与える研究 [Wu 15], および両問題を単一モ デルで表現するためにこれらの特徵量を組み合わせて 与える研究 [Luong 17, Zhao 16], システム発話の意図 を表現可能な音声合成を実現するために対話行為情報 を与える研究 [北条 16a], 感情を表現可能な音声合成を 実現するために感情情報を与える研究 [Inoue 17] など がある. 本研究においてもこれらと同様にDNNに補 助情報を加える立場をとるが, 補助情報として発話の 段落における位置や談話構造上の役割など, 情報伝達 に関連する段落単位での情報を用いている点が異なる. 


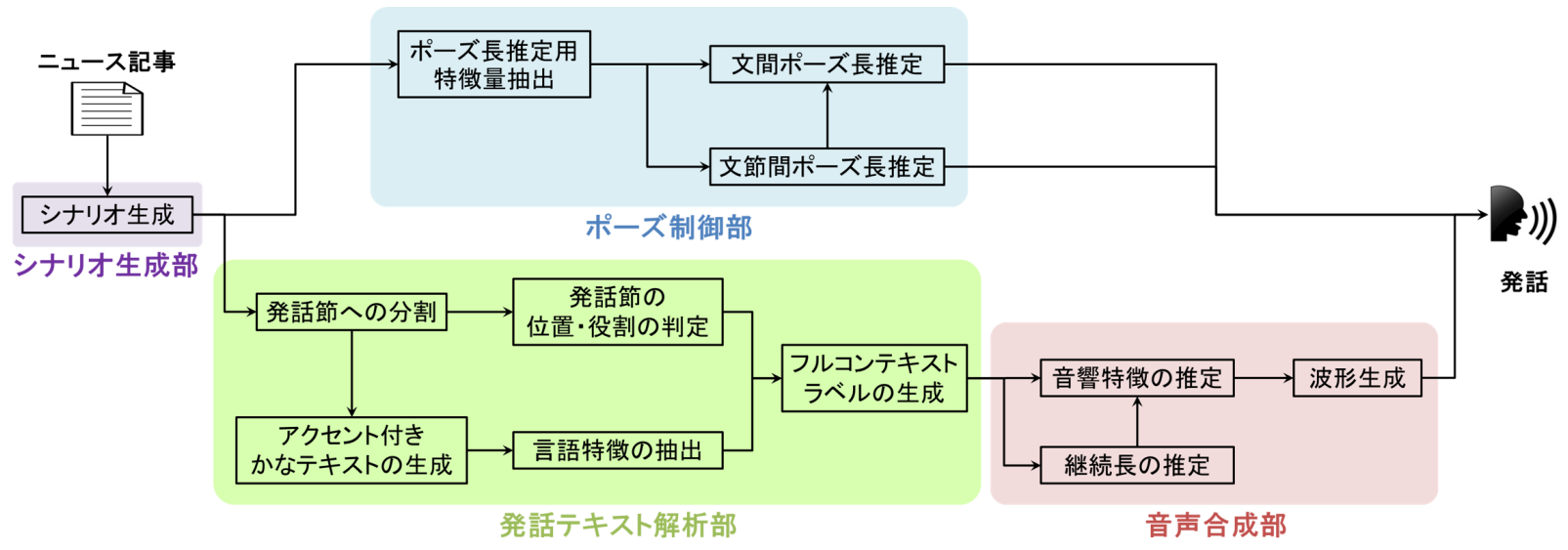

図 1 システム構成図

3. システムの構成

本章では, 開発する音声合成器の組み込み対象であ るニュース伝達用の会話システムにおいて，ニュース 記事が与えられてから，会話で発話するまでの流れを 概説する（図 1).

\section{$3 \cdot 1$ シナリオ生成部}

シナリオ生成部では，ニュース記事から会話のシナ リオを生成する [高津 18a]. シナリオは主計画, 副計 画と呼ぶ, 2 種類の発話計画から構成される. 主計画 は, 二ュース記事など, 伝達対象の文書を要約し, 口語 化することで作られるもので, 文書の要点を伝えるこ とを目的としている。 ユーザーが受け身で聴いている 限り，システムは主計画に従った情報伝達を行う。一 方, 副計画は, 会話進行の各時点におけるユーザーの 反応予測に基づいて，それに対する応答を計画したも ので，ユーザーの興味・理解度に応じた補足情報の提 示を目的としている. ユーザーが能動的な情報要求を 示してきた場合, システムは副計画に遷移し, 情報の 補完を行う。これらの発話計画を事前に準備すること で，即応性の高い円滑な会話インタラクションを実現 できる。

\section{$3 \cdot 2$ 発話テキスト解析部}

テキスト解析部では，シナリオ生成部で生成された 発話文（各文に対して文圧縮と口語化処理を適用し生 成された発話テキスト) から, 音声合成モデルの入力と なる言語特徵の抽出を行う。まず，発話文を「発話節」 というより小さな発話単位に分割する．発話節は，一 息で発話する単位であり，後述するように発話の理解 しやすさを考慮し, 新規情報が複数含まれないように 作られる. 次に，発話節ごとにアクセント句境界およ びアクセント核の推定を行い，アクセントの位置やア クセント句の区切りを記したかなテキストを生成する. このかなテキストを入力として, 音素の種類やアクセ
書き言葉(文)

「宮間や大儀見らが先発した日本は開始直後に先制された」

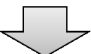

話し言葉(発話節)

\begin{tabular}{l|}
\hline 「日本は宮間とか大儀見とかが先発したんだけど」 \\
「開始直後に先制されたんだって」
\end{tabular}

図 2 発話節への分割例

ント句内のモーラ位置などの言語情報を抽出する.さ らに, 各発話節に対して元記事における段落内の位置 や発話の役割を判定する．発話の役割として「核」「前 置き」「補足」を定め, 要約結果に基づいていずれかの ラベルを各発話節に付与する. そして, 発話節の位置· 役割および言語特徴に関する情報を HTS*3で用いられ ているラベル列（以下，フルコンテキストラベル）へ 変換する.

\section{$3 \cdot 3$ 音声 合成 部}

音声合成部では，フルコンテキストラベルの情報か ら得られる言語特徵や発話節の位置・役割に関する特 徵（以下，発話系列特徵）を入力として，ニューラル ネットワークモデルを用いて継続長と音響特徵を推定 し，推定された音響特徵から STRAIGHT ボコーダー [Kawahara 06] を用いて音声波形を生成する.

\section{$3 \cdot 4$ ポーズ制御部}

ポーズ制御部では, 発話文に対して形態素解析を行 い, 品詞や活用形に関する特徵量を抽出した後, 発話 文内の文節間のポーズ長と発話文間のポーズ長を回帰 モデルで推定する.

\footnotetext{
*3 http://hts.sp.nitech.ac.jp/
} 


\begin{tabular}{|c|c|c|c|c|}
\hline 段落 & 位置 & 役割 & 発話節の内容 & \\
\hline \multirow[t]{3}{*}{1} & 1 & 前置き & 宇宙を観測しているロシアの電波望遠鏡があるんだけど & ( a ) \\
\hline & 2 & 核 & それが正体不明の「強い信号」を検知したっていって注目を集めてるんだって & ( b) \\
\hline & 3 & 補足 & 世界中の天文学者に衝撃が走っているらしいよ & (c) \\
\hline \multirow[t]{3}{*}{2} & 1 & 核 & 信号はヘラクレス座の近くの恒星から届いたんだって & (d) \\
\hline & 2 & 補足 & その星は地球から約95 光年離れていて & (e) \\
\hline & 3 & 補足 & 惑星も持っているみたい & ( f) \\
\hline \multirow[t]{4}{*}{3} & 1 & 前置き & 地球外文明の進歩度を表す基準っていうのがあって & $(\mathrm{g})$ \\
\hline & 2 & 前置き & それと照らしあわせたんだけど & $(\mathrm{h})$ \\
\hline & 3 & 核 & 地球よりもはるかに進歩した文明の可能性があるんだって & (i) \\
\hline & 4 & 補足 & まだ確実なことはわからないんだけどね & $(\mathrm{j})$ \\
\hline
\end{tabular}

図 3 収録で用いた原稿の例

\section{4. 音声データの収録と分析}

ニュース記事をもとに人手で作成した発話原稿を女 性声優に発話させ，音声データの収録を行った． $4 \cdot 1$ 節 では，音声合成用に収録した音声データとその分析結 果について説明し，4·2節では，ポーズ長の推定用に収 録した音声データとその分析結果について説明する.

\section{$4 \cdot 1$ 音声合成用音声データの収録と分析}

\section{$\S 1$ 発話単位}

話し言葉には，音声として発した情報が瞬時に消え る揮発性と，発信した情報が瞬時に聞き手に受信され る同時性という特徵がある [畠 87]. そのため, 話し手 は聞き手の負担を考慮して，一回の発話で伝える情報 はなるべく少なく分かりやすい表現にすることが望ま れる [Chafe 94].

本研究では，伝えようとするニュース記事内の文を， 述語や接続助詞などを手がかりに分割し，それぞれの 区間に複数の新情報が含まれないように発話節を作成 する．例えば，図 2 では連体修飾節と被修飾名詞を切 り離し（主節化分割 [後藤 16]）, 接続助詞を挟んだう えで，末尾を伝聞口調に書き換える [高津 18a]. 接続 助詞を区切りとして分割された二つの文節列が発話節 となり，一息で発話する単位となる.

\section{$\S 2$ 発話節の役割}

情報を伝える発話節の役割として「核」(Nucleus)， 「前置き」(Front Satellite)，「補足」(Rear Satellite）の 3 種類を採用する。ここでの核は修辞構造理論 [Mann 88]における核（Nucleus）と同等のもので，ニュース の重要な情報を伝える役割をもつ，前置き，補足は修 辞構造理論における衛星（Satellite）にあたるものであ る. 核の前に位置し，情報を伝えるリード文の役割を 果たす発話節を前置きとする，核の後に位置し，核の

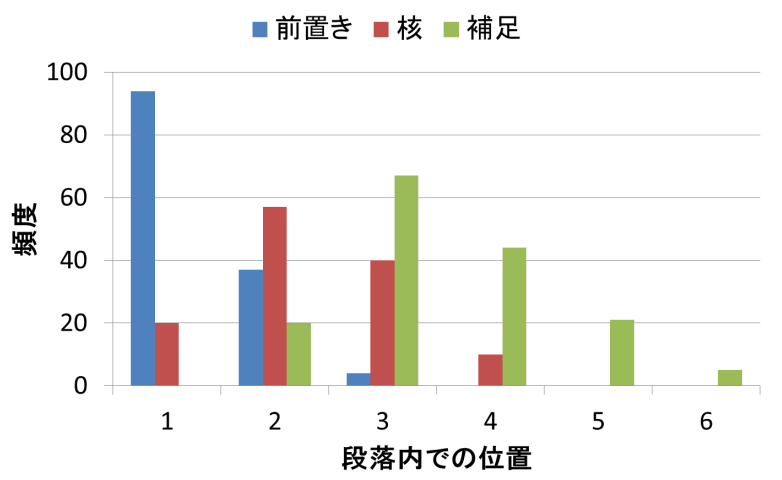

図 4 役割ごとに見た発話節の段落内での出現位置の分布

情報を補ったり，核ほど重要ではないが付加すべき情 報を伝える役割を果たす発話節を補足とする。

\section{$\S 3$ 収録原稿の作成}

収録原稿の例を図 3 に示す．図 3 の例では各行が発 話節となっており，（a）〜（c）などの空行で区切られ た単位が一つの段落を構成している.

各発話節の役割は，図 3 の太字で示した（b)，(d)， （i）が核，核の前にある（a)，(g)，（h）が前置き，核 の後ろにある (c), (e), (f), (j) が補足である.

原稿の作成にあたり, 段落は $3 \sim 6$ 個程度の発話節か らなり，必ず 1 個以上の核を持つように設計した。前 置きと補足は複数存在する場合もあるが，核の位置に よっては存在しないことを許す．段落の最初が核の場 合は前置きが，最後が核の場合は補足が存在しなくな る．核としては，ニュース記事の見出しなどの重要な 情報を含むものを選択した。また，収録にあたり，核 となる発話節は太字で明記した。

合計 39 記事（114 段落，419 発話節）からなる原稿 を作成した. 図 4 は，それぞれの役割の発話節が段落 内の何番目に現れているかを表したものである。この 図から前置きは 1 番目や 2 番目といった段落の前方に, 


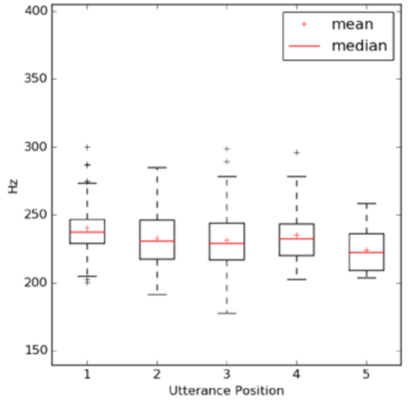

(a) 発話節全体のFO平均

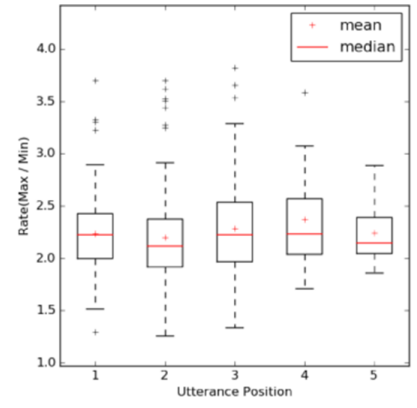

(b) 発話節全体のFOダイナミックレンジ

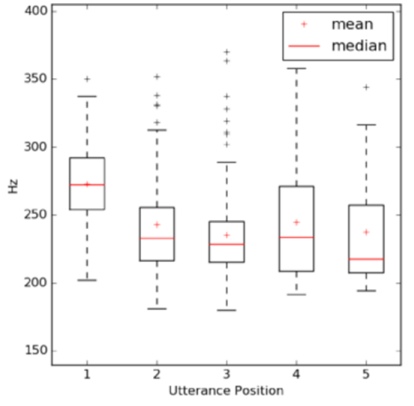

(c) 発話節冒頭のFo平均

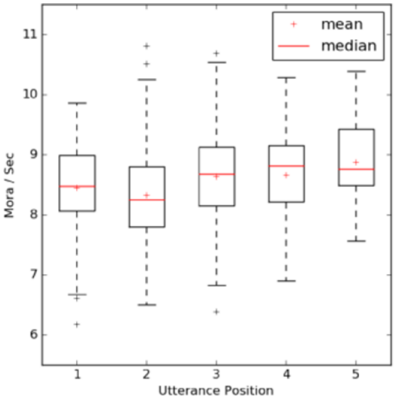

(d) 発話速度

図 5 発話節の位置による韻律の違い

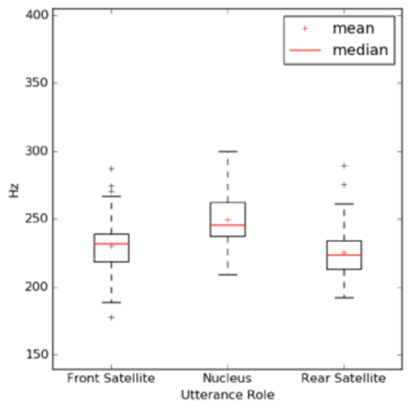

(a) 発話節全体のFo平均

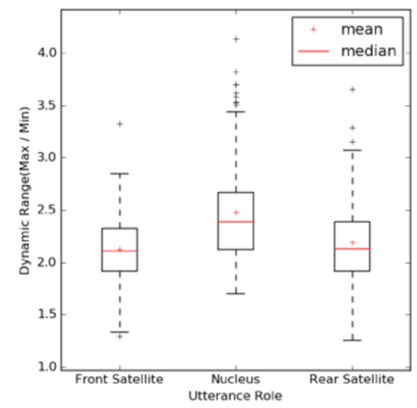

(b) 発話節全体のFOダイナミックレンジ

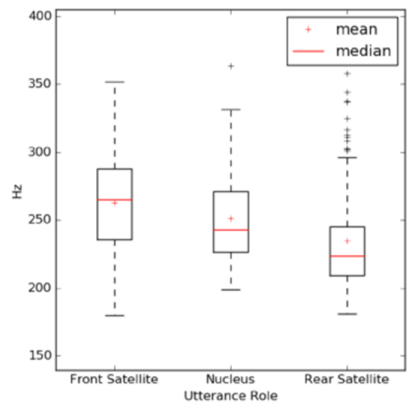

(c) 発話節冒頭のFO平均

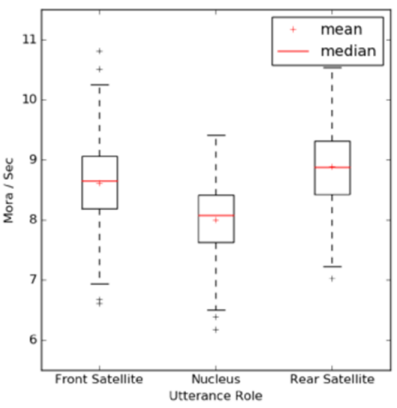

(d) 発話速度

図 6 発話節の役割による韻律の違い

核は 2 番目や 3 番目に, 補足は 3 番目以降に多く現れ ていることが分かる.

\section{$\S 4$ 収録概要}

女性声優 1 人に原稿を発話させることで, 段落ごと に音声データの収録を行った。収録時には以下の点を 意識するように指示を与えた。

（1）太字で示された内容が相手にはっきりと伝わるよ うに話すこと

（2）話し相手がうなずきながら聴いているものとして， 途中で大きく間（ま）をあけることなく話すこと

（3）日常会話のような口調で, 話し相手にニュースの 内容を伝えるつもりで話すこと

$\S 5$ 発話節の位置と役割による韻律の違いに関する 分析

収集した発話音声について, 発話節の基本周波数 (F0) や発話速度の変化に関する統計を調査した。

標本化周波数は $16 \mathrm{kHz}$ とした. F0 の抽出にはSTRAIGHT

[Kawahara 06] を使用し, フレーム長 40ms, フレーム シフト $1 \mathrm{~ms}$ で抽出を行った. 発話速度は 1 秒あたりの モーラ数と定めた．発話速度を計算するための音素ア ライメントにはJulius*4を用いた。

*4 http://julius.osdn.jp/
各発話節に対して, 発話節全体の F0 平均, 発話節全 体の F0 ダイナミックレンジ，発話節冒頭の F0 平均, 発話速度を算出した。発話節の位置と韻律の関係を図 5 に，発話節の役割と韻律の関係を図 6 に示す.

発話節全体の F0 平均の分布 (図 $5(\mathrm{a})$, 図 $6(\mathrm{a})$ ) を 見ると，発話節の役割の影響が強く出ており，核とな る発話節の $\mathrm{F} 0$ 平均が高くなっている。これは発話節 全体の F0 のダイナミックレンジ（図 5（b), 図 6(b)) でも同様である.

一方, 発話節冒頭 3 モーラの F0 平均值を調べたとこ 万（図 5 (c)，図 6 (c)), 位置の影響が強くなってお り，特に 1 番目の発話節冒頭では F0 が高い值を取っ ている．役割についても前置きの発話節冒頭の F0 平 均が高くなっている.これは図 4 に示したように前置 きの発話節の多くは 1 番目の位置に現れることに起因 するものと考えられる．段落の最初の発話節冒頭で F0 が上がっている現象は，聞き手に注意を向けさせるた めの合図としての役割を果たしていると推察される。

発話速度（図 $5(\mathrm{~d})$, 図 $6(\mathrm{~d}))$ については役割の影 響が強く出ており，核の役割を持った発話節が他と比 較してゆっくり発話されていることが見て取れる．位 置との関係（図 $5(\mathrm{~d}))$ を見ると，2 番目の発話節の発 話速度が低下していることが分かる。これは図 4 に示 したように核の発話節が 2 番目に多く現れることに起 因するものと考えられる。 
表 1 ポーズ長タグ付きコーパスの統計

\begin{tabular}{c|c|c}
\hline \hline & 文節間のポーズ長 & 発話文間のポーズ長 \\
\hline データ数 & 5327 & 507 \\
\hline 最小值（秒） & 0.000 & 1.172 \\
\hline 平均值（秒） & 0.210 & 2.657 \\
\hline 最大值（秒） & 2.680 & 4.283 \\
\hline
\end{tabular}

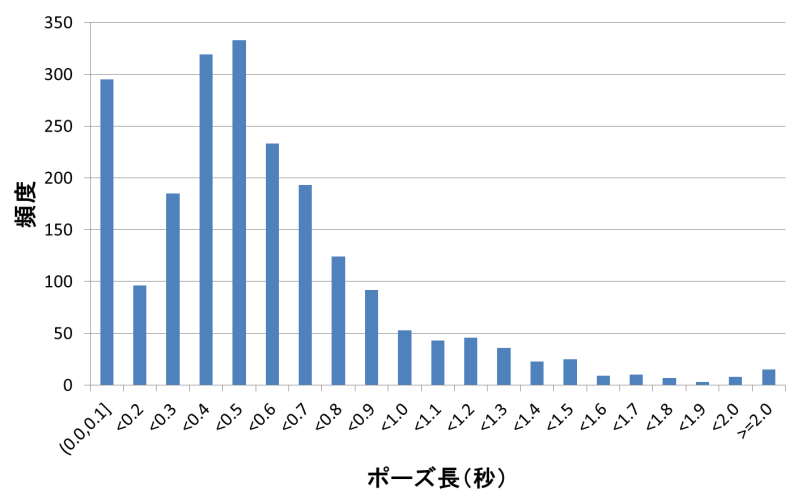

図 7 発話文内の文節間のポーズ長（非ゼロ）の分布

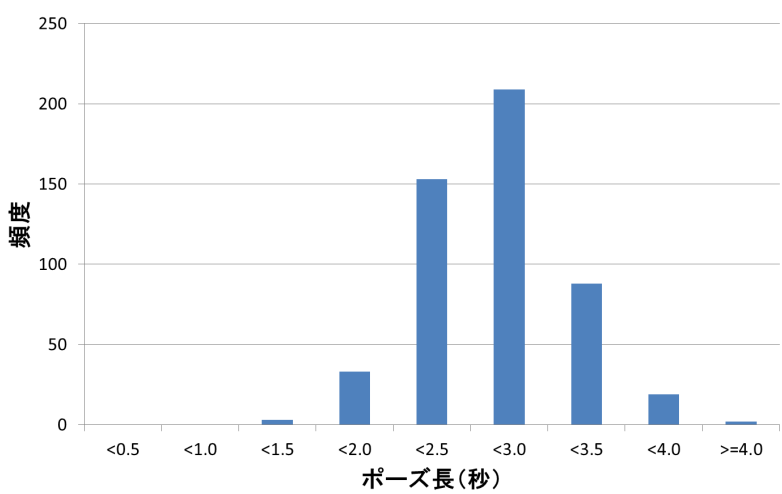

図 8 発話文間のポーズ長の分布

$4 \cdot 2$ ポーズ長推定用音声データの収録と分析

音声合成用のデータの収録では，聞き手は話し手の 話を傾聴しているものとして，相手のフィードバック を待つような大きな間（ま）をあけることなく話すよ うに指示した。しかしながら，実際の会話では，相手 に理解を促したり，相手の理解状態をうかがったりす るために，適度に間（ま）を入れながら話を進める。本 節では，特にまとまった量の情報を伝える際の間（ま） の取り方に焦点を当てて音声収録を行った。

\section{$\S 1$ 収録概要}

テクノロジー系のニュース記事 100 個から人手で作 成した発話原稿を女性声優 1 人に発話させ，その発話 音声を収録した。ここでは，自然に出てくる間（ま）の データを収集するために，原稿には核の情報や発話節 の区切りを明示しなかった。収録にあたり，話者に対 して以下の点に注意するように指示した。
表 2 収録音声から得られたポーズ長の例（太線が発話文の区切り， 細線が発話節の区切り)

\begin{tabular}{|c|c|c|}
\hline 発話節の役割 & 発話内容 & ポーズ長（ミリ秒） \\
\hline \multirow{6}{*}{ 前置き } & いま & 181 \\
\hline & 国内の & 0 \\
\hline & 自動車市場って & 383 \\
\hline & ミニバンとか & 0 \\
\hline & エコカーが & 0 \\
\hline & 主力なんだけど & 650 \\
\hline \multirow{3}{*}{ 核 } & 高級スポーツカーの & 0 \\
\hline & 売れ行きも & 0 \\
\hline & 好調らしいよ & 1620 \\
\hline \multirow{4}{*}{ 前置き } & 日産が & 0 \\
\hline & GT-R を & 0 \\
\hline & 9 年ぶりに & 0 \\
\hline & 改良して & 716 \\
\hline \multirow{4}{*}{ 前置き } & 今年の & 0 \\
\hline & 7 月に & 0 \\
\hline & 新モデルを & 0 \\
\hline & 発売したんだけど & 853 \\
\hline \multirow{2}{*}{ 核 } & 996 万円以上も & 0 \\
\hline & するのに & 394 \\
\hline \multirow{6}{*}{ 核 } & 1 か月で & 0 \\
\hline & 年間販売計画台数の & 129 \\
\hline & 800 台を & 0 \\
\hline & 超える & 0 \\
\hline & 受注が & 0 \\
\hline & あったんだって & 2292 \\
\hline
\end{tabular}

（1）話を聴いている相手に内容を伝える（理解させる） つもりになって発話すること

（2）重要な箇所は強調し，あまり重要でない箇所はさ らっと伝えるなど，メリハリのある話し方を意識 すること

（3）発話中でも割り込んで質問がくる可能性があり, 質問がくると予想される箇所では不自然でない程 度に間（ま）を入れること

\section{$\S 2$ データセットの分析}

収録した音声から文節間のポーズ長および発話文間 のポーズ長に関する時間情報を算出し，ポーズ長タグ 付きコーパスを作成した。ここで，文節区切りにはJU$\mathrm{MAN}++^{* 5}$ と $\mathrm{KNP}^{* 6}$ の結果を採用した。データセット の統計を表 1 に示す。 また，発話文内の文節間のポー ズ長と発話文間のポーズ長の分布をそれぞれ図 7 と図 8 に示す.

実際に収録音声から得られたポーズ長の例を表 2 に 示す。この図から，発話文と発話文の間のポーズ長は 2 秒程度であり，発話文内の文節間のポーズ長は，連 用節の後, つまり，発話節の区切りとなる場所で比較 的長めのポーズが設けられていることが分かる.

\footnotetext{
*5 http://nlp.ist.i.kyoto-u.ac.jp/index.php? JUMAN ++

*6 http://nlp.ist.i.kyoto-u.ac.jp/index.php? $\mathrm{KNP}$
} 
表 3 アクセント付きかなテキストの生成例

\begin{tabular}{|c|c|}
\hline 入力 & $\begin{array}{l}\text { 地球から } 340 \text { 光年離れたところである惑星が見つかった } \\
\text { んだけど }\end{array}$ \\
\hline 出力 & $\begin{array}{l}\text { ち）きゆーから//さ@んびゃく/よんじゅっこ@ーね } \\
\text { ん/はな@れた/ところ@で//ある/わく)せーが／ } \\
\text { みつ）かった@んだけど }\end{array}$ \\
\hline
\end{tabular}

表 4 アクセント付きかなテキストの構成

\begin{tabular}{cll}
\hline \hline 表記 & 意味 \\
\hline ひらがな & 発話節内容 (読み) & \\
@ & アクセント位置 & \\
$\nearrow$ & アクセント句区切り & 前の句が直後の句を修飾 \\
$\nearrow /$ & アクセント句区切り & 前の句が2つ以上後ろの句を修飾 \\
$:$ & ポーズ & \\
) & 母音の無声化 & 母音「い」と「う」が対象 \\
\hline
\end{tabular}

5. 発話節の位置・役割を考慮した音声合成 手法

前章では，ニュースを伝える発話系列音声において， 発話節の位置と役割が韻律に影響を与えていることを 確認した。本章では, 従来の DNN 音声合成モデルに これらを補助情報として組み込んだモデルを提案する. まず, 音声合成器の入力となる言語特徵を得るための 発話テキストの解析方法について説明する. 次に, 発 話節の位置や役割（発話系列特徵）を考慮した DNN 音 声合成モデルについて説明する，最後に，発話節間の ポーズ長を推定するモデルについて説明する.

\section{$5 \cdot 1$ 発話テキストの解析}

\section{$\S 1$ 発話節への分割}

発話節への分割は，ニュース記事の各文に文圧縮・ 口語化処理 [高津 18a] を行うことで生成された発話文 を連用節や連体修飾節の位置で区切ることで行う（図 2).ただし, 連体修飾節の位置での分割において, 被 修飾名詞が形式名詞・副詞的名詞である場合や残りの 文節数が 2 文節以下のように短い場合は分割しない。

\section{$\S 2$ 発話節の位置・役割判定}

発話節の位置は, 段落内で何番目の発話節かを表す. 発話節の役割は, 要約処理 [高津 18a] で重要文として 抽出された文を「核」とする. 段落内で核の文よりも 前にあるものを「前置き」とし，段落内で核よりも後 ろにあるものを「補足」とする（図 3)。ただし，核の 文でも複数の発話節に分割される場合は, 最初のもの を前置きとし，以降のものを核とする．また，核を持 たない段落の文は, 後ろに核を持つ段落が存在する場 合は前置きとし, 後ろに核を持つ段落が存在しない場 合は補足とする.
§ 3 アクセント付きかなテキストの生成

発話節のテキストを入力として，アクセント付きか なテキストを生成する. 入力と出力の例を表 3 に示す. また，かなテキストの構成を表 4 に示す．アアクセント 位置およびアクセント句区切りは, LSTM を用いたモ デルによって推定する [小野 18].

\section{$\S 4$ フルコンテキストラベルの生成}

フルコンテキストラベルは, 音素ごとにコンテキスト を考慮した属性（音素の種類やアクセント句内のモー ラ位置など）を付与したラベル列である. 本研究では, 従来用いられてきた音素レベルから発話レベル（ここ では発話節レベル）の属性 [Iwata 11] に加え, 発話節 の位置や役割を付与したものを用いる.

\section{2 発話系列特徵を考慮した DNN 音声合成モデル}

従来の DNN 音声合成モデルに, 発話節の位置や役 割に関する特徵（発話系列特徵）を加えたモデルを提 案する.

Zen らは, 言語特徵を入力として音響特徵を予測す る DNN 音声合成モデル（以下，音響モデル）を提案 した [Zen 13]. Zen らのモデルでは，音響モデルの入 力とする継続長には自然音声から得られた継続長が用 いられているが，Wu らの DNN 音声合成ツールキット Merlin*7[Ronanki 16, Wu 16] では, 継続長の推定にも DNN（以下, 継続長モデル) を用いている. 本研究で は, モデルの作成, 学習に Merlin を使用した。

提案モデルの概要を図 9 に示す．まず，フルコンテ キストラベルから DNN の入力となる言語特徵を抽出 する．言語特徴には，音韻に関する質問（子音かどう かなど) の解答といったバイナリ特徵や, 発話文のアク セント句の数といった数值特徵が含まれる. 継続長モ デルでは, 言語特徵を入力として各音素の継続長を出 力するニューラルネットワークを構築する. 出力され た継続長をもとにフレーム特徴 [Wu 16] を計算し，言 語特徴とともに音響モデルの入力とする.

提案モデルでは, 入力に言語特徵やフレーム特徴に 加えて発話節の位置・役割を表す特徵 (発話系列特徵) を与える，発話節の位置に関する情報は，現在の発話 節が段落内の何番目であるかを 1 次元の整数值で表現 する．発話節の役割に関する情報は，対象の発話節が 前置き, 核, 補足のどの役割に該当するかを one-hot な 3 次元のベクトルで表現する.つまり，該当する役割 の次元が 1 になりその他が 0 の值をとる.これら 4 次 元の発話系列特徴を言語特徴やフレーム特徵に加えて, 継続長モデルと音響モデルの入力に与える. 


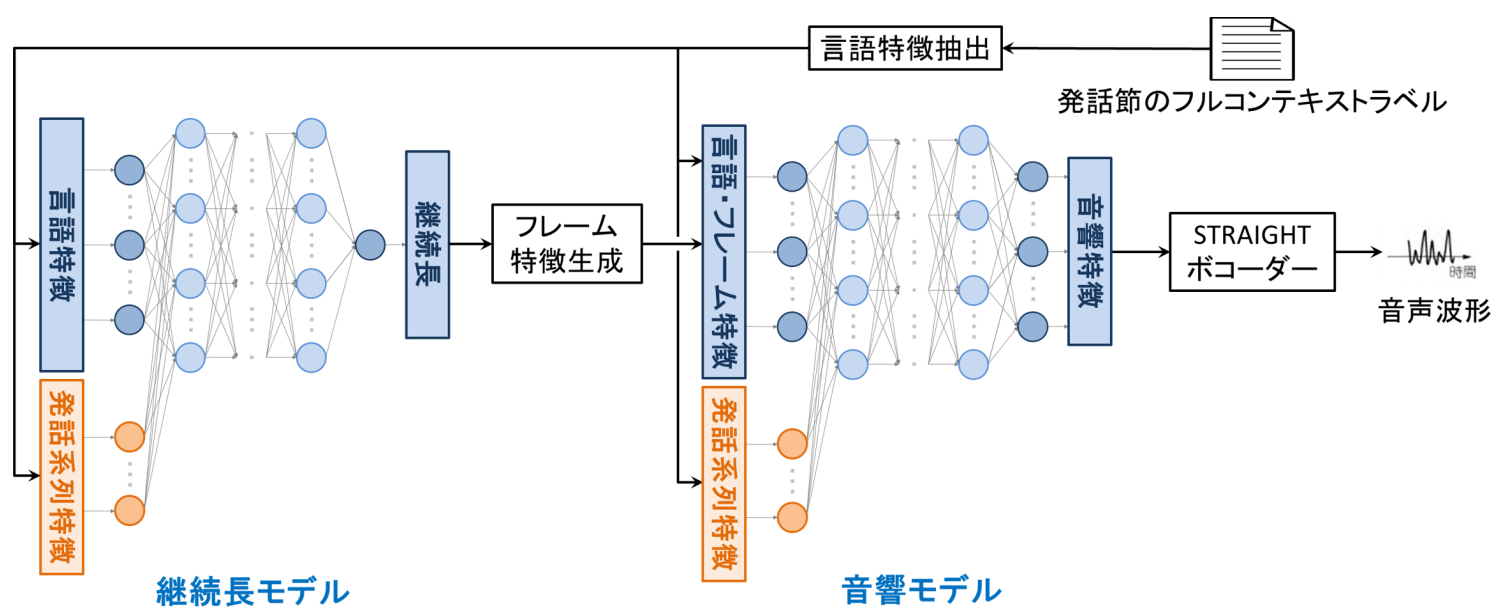

図 9 発話系列特徵を考慮した DNN 音声合成モデル

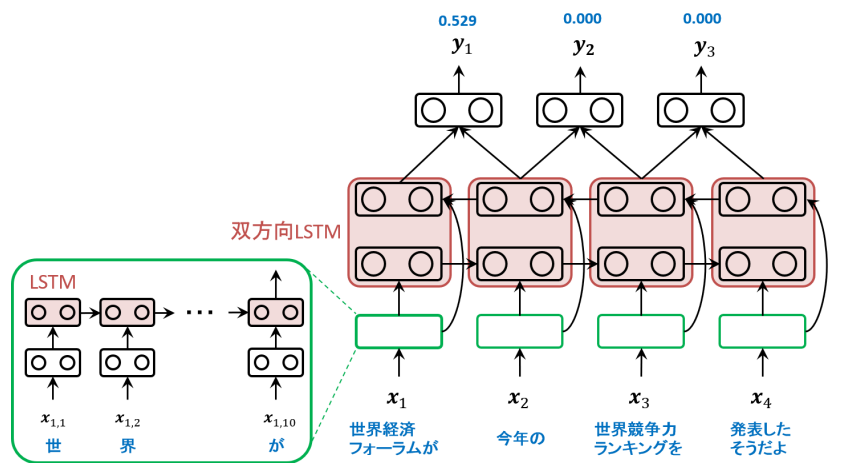

図 10 文節間ポーズ長推定モデル

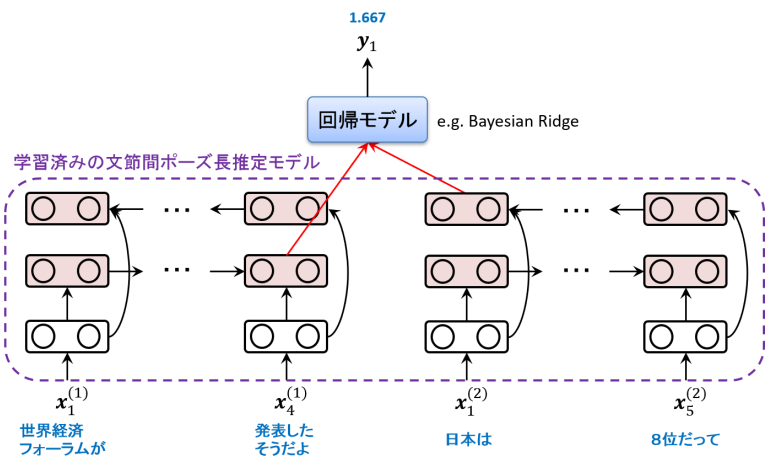

図 11 文間ポーズ長推定モデル

\section{$5 \cdot 3$ ポーズ長の推定}

$4 \cdot 2$ 節の分析で発話文内の文節間のポーズ長と発話 文間のポーズ長の分布が大きく異なっていることが分 かった。そこで，発話文内の文節間のポーズ長を推定 するモデル（以下，文節間ポーズ長推定モデル）と発 話文間のポーズ長を推定するモデル（以下，文間ポー ズ長推定モデル）の 2 つのモデルを用いてポーズ長を 推定する。なお，音声合成時にも発話節内のポーズ長 が推定されるため，音声合成結果と間（ま）の制御を 統合して会話を行う際は，発話節内のポーズ長は音声 合成結果のものを採用し，本節のモデルで推定された ポーズ長は発話節間の間（ま）の部分に用いる.

\section{$\S 1$ 文節間ポーズ長推定モデル}

発話文内の文節間のポーズ長を推定するモデルを提 案する。モデルには順方向 1 層, 逆方向 1 層の双方 向 LSTM を用いる．文節間のポーズ長は前後の文節の LSTM の状態に基づいて推定する（図 10）。入力は文 節ごとに文字の系列を 1 層の LSTM でリカレントに埋 め込んだものを与える。この際，文字の one-hot 表現 に加え，単語の品詞や活用形の情報を与える。そして， 実際に声優が発話したときのポーズ長を予測するよう に誤差逆伝播法でモデルの学習を行う.

\section{$\S 2$ 文間ポーズ長推定モデル}

発話文間のポーズ長を推定するモデルを提案する。 発話文間の間 (ま) の役割として, 発話内容の咀嚼 · 理解や質問誘発の他に，話題変更の合図が考えられる. そのため, 現在の発話内容だけでなく, 次の発話内容 も考慮してポーズ長を決定する必要がある．ここでは, $5 \cdot 3 \S 1$ 節で学習したモデルを用いて, 現在の発話文に おける順方向 LSTM の最終文節の隠れ層の值と次の発 話文における逆方向 LSTM の先頭文節の隠れ層の值を 特徵量として，リッジ回帰により発話文間のポーズ長 を推定する（図 11）。また，特徵量には前後の発話文 の単語数も加える.

\section{6. 評価実験 1: モデルの性能評価}

収録した音声データを用いて, 音声合成モデルとポー ズ長推定モデルの評価を行った。

\section{$6 \cdot 1$ 音 声 合 成}

発話系列特徵を加えないモデルをベースライン，発 話系列特徵を加えたモデルを提案モデルとして性能の 比較を行った。 
表 5 発話系列特徵の有無による性能の比較

\begin{tabular}{l|c|c|c|c}
\hline \hline & F0-RMSE & dur-RMSE & MCD & BAD \\
\hline ベースライン & 36.420 & 4.779 & 5.064 & 0.660 \\
\hline 提案モデル & $\mathbf{3 5 . 4 3 5}$ & $\mathbf{4 . 7 6 8}$ & $\mathbf{5 . 0 4 7}$ & $\mathbf{0 . 6 5 9}$ \\
\hline
\end{tabular}

\section{$\S 1$ 実験設定}

データセットとして $4 \cdot 1$ 節で収録した 419 個の発話 節からなる音声データとシナリオを用いた。ここで, 発話節の位置・役割の付与, および, アクセント付き かなテキストの作成までの処理は人手で行った.

合成フィルタには STRAIGHT [Kawahara 06] を使用 した。音響特徴量は, 0-39 次元のメルケプストラム, 1 次元の対数 F0，5 次元の帯域ごとの非周期性指標およ び，これらの $\Delta, \Delta^{2}$ と，1 次元の有声／無声区間判定 （有声区間なら 1, 無声区間なら 0）の計 139 次元から なる．音声データからの音響特徵量の抽出は $4 \cdot 1 \S 5$ 節 と同様の条件で行った。

DNN の隠れ層は 6 層でユニット数は 1024 に設定し， 中間層の活性化関数には tanh, 最適化アルゴリズムに は Adam を使用した。

\section{$\S 2$ 実験結果}

10 分割交差検定でモデルの出力と元データの音響特 徵量の誤差を計算した結果を表 5 に示す。ここで, F0RMSE, dur-RMSE は基本周波数, 音素継続長の平均二乗 誤差平方根（Root Mean Square Error）を表し, MCD, BAD はメルケプストラム歪み（Mel-Cepstrum Distortion), 帯域ごとの非周期性指標の歪み(Band-Aperiodicity Distortion）を表している. なお, 音響モデルの入力に は, 原音声の継続長を使用した。

基本周波数, 継続長に関して, 4 次元の発話系列特徵 を加えることでベースラインに比べて誤差が小さくな ることが確認できた。 また, メルケプストラム, 非周 期性指標についても発話系列特徴を加えることでわず かに改善が見られた。

\section{2 ポーズ長の推定}

$4 \cdot 2$ 節で作成したポーズ長タグ付きコーパスを使用 し，文節間ポーズ長推定モデルと文間ポーズ長推定モ デルに関して, 有効な特徵量の検討および性能の評価 を行った。

\section{$\S 1$ 文節間のポーズ長の推定}

モデルの構造として, 文節を構成する単語や文字の Bag-of-Words（BoW）を入力として与えたときと, こ れらをLSTM でリカレントに埋め込んだときの平均二 乗誤差平方根 (RMSE) の比較を行った. さらに, 単語 や文字の基本素性の他に JUMAN++や KNP を適用し て得られる品詞や活用形, 活用型, カテゴリ, ドメイ
表 6 文節間ポーズ長推定モデルの結果（RMSE）

\begin{tabular}{c|c|c|c|c}
\hline \hline 追加素性 & 単語 BoW & 文字 BoW & 単語 RNN & 文字 RNN \\
\hline & 0.252 & 0.260 & 0.251 & 0.233 \\
\hline 品詞 & 0.234 & 0.240 & 0.231 & 0.224 \\
\hline 活用形 & 0.239 & 0.242 & 0.230 & 0.230 \\
\hline 活用型 & 0.245 & 0.255 & 0.237 & 0.229 \\
\hline カテゴリ & 0.253 & 0.261 & 0.249 & 0.236 \\
\hline ドメイン & 0.252 & 0.259 & 0.248 & 0.233 \\
\hline 固有表現 & 0.250 & 0.260 & 0.250 & 0.236 \\
\hline 親密度 & 0.263 & 0.264 & 0.250 & 0.243 \\
\hline 難易度 & 0.260 & 0.262 & 0.249 & 0.242 \\
\hline 品詞+活用形+活用型 & & & & $\mathbf{0 . 2 1 9}$ \\
\hline
\end{tabular}

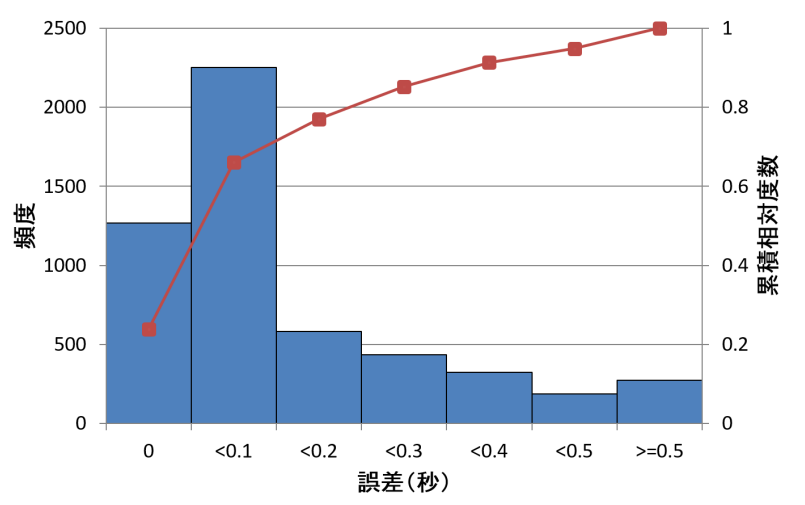

図 12 文節間ポーズ長の誤差（折れ線は累積相対度数）

ン, 固有表現の他, 『基本語データベース』*8の単語親 密度および『日本語教育語彙表 ver1.0』*9の語彙難易 度を追加素性として使用し, 有効な素性の組み合わせ について検討した。なお，ポーズ長の推定結果が読点 「、」の与え方に左右されないように，入力文から「、」 を取り除いた。実験では, 埋め込み層および隠れ層の 次元を 100 次元に設定し, 活性化関数には $\tanh$, 最適 化アルゴリズムには Adam を使用した。

10 分割交差検定により評価した結果を表 6 に示す. 実験の結果から，文節の文字をリカレントに入力した ときの結果が総じて良く, 追加素性として品詞と活用 形および活用型の情報を与えたときに最も RMSEが小 さな值を示した。さらに, 推定值と正解の誤差のヒス トグラム（図 12）を確認したところ，0.2 秒未満の誤 差の割合が 77\%であった.

\section{$\S 2$ 発話文間のポーズ長の推定}

特徵量として前節で学習した文節間ポーズ長推定モ デルの LSTM の隠れ層の值を用いた。予備実験の結果, 現在の発話文における順方向 LSTM の最終文節の隠れ 層の值と次の発話文における逆方向 LSTM の先頭文節 の隠れ層の值の組み合わせが最も良い結果を示した. また, scikit-learn*10の回帰モデルを一通り比較した結

\footnotetext{
*8 https://hon.gakken.jp/reference/special/ jiten/kihongo_db/index.html

*9 http://jhlee.sakura.ne.jp/JEV.html

*10 http://scikit-learn.org/stable/
} 


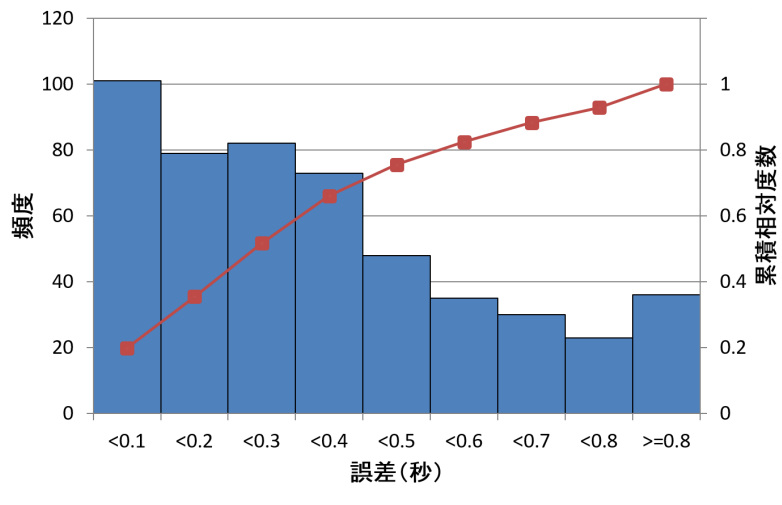

図 13 文間ポーズ長の誤差（折れ線は累積相対度数）

果, BayesianRidge モデルが最も良い結果を示した。

10 分割交差検定で評価したところ, RMSE は 0.450 で あった。ポーズ長が前後の発話の長さに影響されると いう研究報告もあり [鴨井 11], 前後の発話の文字数, 単 語数，文節数を素性に加えて比較したところ，RMSEは 文字数を加えた場合 0.440 , 単語数を加えた場合 0.436 , 文節数を加えた場合 0.437 を示した。この結果から発 話の長さに関与するこれらの特徵量を加えることの有 効性が確認された。さらに，単語数を加えたモデルに おいて，推定值と正解の誤差のヒストグラム（図 13） を確認したところ，0.5 秒未満の誤差の割合が $75 \%$ で あった。

\section{$\S 3$ ポーズ長の推定結果の例}

10 分割交差検定で得られたポーズ長の推定結果の例 を表 7 に示す。この結果から，提案モデルの推定結果 が人の話し方に近い間（ま）の取り方になっているこ とが分かる。また，音声収録において指示した「質問 が予測される箇所で不自然でない程度に間（ま）を入 れる」という部分に関して，実際に声優は 1 発話文目 の「あるんだけど」の後，および， 3 発話文目の「使っ てて」の後に十分な間（ま）をあけており，システム もそれを再現できている。

\section{7． 評価実験 2: 情報を伝える話し方としての ふさわしさに関する主観評価}

音声合成モデルの学習に用いる音声データの発話単 位，間（ま）の制御の有無，発話系列特徵の利用の有 無の 3 つの条件を変えて合成音を作成し，情報を伝え る話し方としてのふさわしさについて評価を行った。

\section{$7 \cdot 1$ 実 験 概 要}

音声合成モデルの学習に用いる音声データの発話単 位に関して，「単発話」と「段落発話」の比較を行った。 ここで，単発話は，学習データを一文ずつ発話・収録
表 7 ポーズ長の推定結果（ミリ秒）（「推定結果の間」と「人の間」 のいずれかが 100 ミリ秒以上であった箇所．太線は発話文の 区切り, 細線は発話節の区切り)

\begin{tabular}{l|r|r}
\multicolumn{1}{c|}{ 発話内容 } & 推定結果の間 & 人の間 \\
\hline \hline ジュノっていう & 61 & 210 \\
無人探査機があるんだけど & 1085 & 1311 \\
\hline それが撮影した & 329 & 417 \\
木星の北極と南極の画像を & 412 & 581 \\
NASAが公開したそうだよ & 2700 & 2630 \\
\hline 太陽系の & 214 & 0 \\
他の惑星には見られない & 459 & 641 \\
\hline 雲とかの気象が見れるみたい & 2503 & 2553 \\
\hline 撮影には & 308 & 375 \\
オーロラマッピング装置を使ってて & 832 & 1272 \\
\hline これまで観測されなかった & 394 & 376 \\
周囲と温度が違うスボットを捉えたんだって & 2521 & 2453 \\
\hline それで & 544 & 667 \\
木星の & 238 & 262 \\
オーロラの謎が解明できるんじゃないかって & 511 & 388 \\
期待されてるそうだよ & & \\
\hline
\end{tabular}

表 8 比較する合成音声の種類

\begin{tabular}{c|c|c|c|c}
\hline \hline $\begin{array}{c}\text { 合成音声 } \\
\text { タイプ }\end{array}$ & $\begin{array}{c}\text { 単発話 } \\
\text { モデル }\end{array}$ & $\begin{array}{l}\text { 段落発話 } \\
\text { モデル }\end{array}$ & $\begin{array}{l}\text { 間（ま） } \\
\text { の調整 }\end{array}$ & $\begin{array}{l}\text { 発話系列 } \\
\text { 特徵 }\end{array}$ \\
\hline 1 & $\checkmark$ & & & \\
\hline 2 & $\checkmark$ & & $\checkmark$ & \\
\hline 3 & & $\checkmark$ & $\checkmark$ & \\
\hline 4 & & $\checkmark$ & $\checkmark$ & $\checkmark$ \\
\hline
\end{tabular}

することを表す。一方，段落発話は，4.1 節で説明し た，核を明示し，複数の発話節からなる発話系列を段 落単位で発話・収録することを表す．段落発話モデル の学習には, $4 \cdot 1$ 節で収録した音声データを使用し, 単 発話モデルの学習には，音素バランスのとれた会話調 の 700 発話 [Iwata 11, 小林 14] を段落発話と同じ声優 で別途収録した音声データを使用した。

間（ま）の制御に関しては，発話節間のポーズ長とし て，5.3 節で提案したポーズ長推定モデルの推定結果 を用いたものと，4·1 節で収録した音声データにおけ る核から核へ移行する際の平均時間に相当する 0.5 秒 に固定したものとを比較した。

発話系列特徴の利用に関しては，発話節の位置・役 割に相当する発話系列特徵を DNN の補助情報として 利用した場合と利用しない場合を比較した。

10 個のニユーストピックについて，これらの組み合 わせによって表 8 に示す 4 タイプの音声を合成し，下 記 3 つのタスクについて一対比較による評価を行つた. サンプル音声は， 1 記事あたり 3 段落程度の発話系列 からなる約 1 分の音声である。

タスク $\mathbf{A}$ 間（ま）の調整の有無に関する比較（タイ プ 1 とタイプ 2 の合成音声の比較） 
単発話モデル(間(ま)の調整なし, 発話系列特徵なし) 口 単発話モデル(間(ま)の調整あり, 発話系列特徴なし)

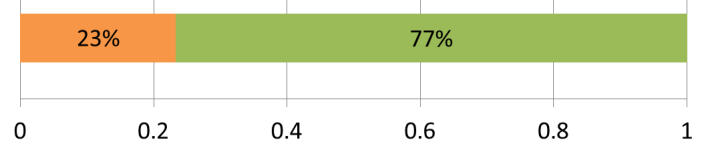

図 14 【実験 2】タスク A : 間（ま）の調整の有無に関する比較

笚発話モデル(間(ま)の調整あり, 発話系列特徴なし) 曰段落発話モデル(間(ま)の調整あり, 発話系列特徵なし)

\begin{tabular}{|l|l|l|l|l|l|}
\hline \multicolumn{3}{|c|}{$21 \%$} & \multicolumn{5}{c|}{$79 \%$} \\
\hline & & & & \\
\hline & & & & & \\
\hline & 0.2 & 0.4 & 0.6 & 0.8 & 1
\end{tabular}

図 15 【実験 2】タスク B : 単発話モデルと段落発話モデルの比較

ロ段落発話モデル(間(ま)の調整あり, 発話系列特徵なし) ロ 段落発話モデル(間(ま)の調整あり, 発話系列特徵あり)

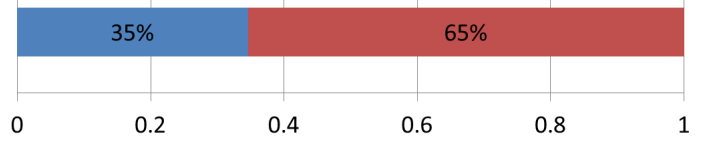

図 16 【実験 2】タスク $\mathrm{C}$ : 発話系列特徵の有無に関する比較

タスク B 単発話モデルと段落発話モデルの比較（タ イプ 2 とタイプ 3 の合成音声の比較）

タスク $\mathrm{C}$ 発話系列特徵の有無に関する比較（タイプ 3 とタイプ 4 の合成音声の比較）

評価は「情報を伝える話し方としてどちらがよりふ さわしいと感じたか」という観点で，被験者 15 人に対 して実施した。各タスクは被験者ごとにランダムな順 序で実施し，比較する音声に関しても提示順序をラン ダムにして聴かせた。 また，音声を複数回聴くことを 許容した。サンプル音声は， 1 記事あたり 3 段落程度 の発話系列からなる約 1 分の音声である. なお, 図 1 のシナリオ生成部で主計画を作成する処理（要約と口 語化）は人手で行った.

\section{$7 \cdot 2$ 実 験 結 果}

各タスクの実験結果を図 14, 図 15, 図 16 に示す.

間（ま）の調整の有無に関する比較では，一定の短 い間（ま）で淡々と発話する話し方よりも, 内容に応 じて間（ま）の長さを調節する話し方の方が情報を伝 える話し方としてふさわしいとする結果が得られた。

単発話モデルと段落発話モデルの比較では, 段落発話 モデルの方が良い結果が得られた。段落発話モデルの 学習データは, まとまった量の情報を伝えることを強 く意識して収録した音声データである，そのため，一
発話に限ってみても, 抑揚の付け方や話速が単発話モ デルよりもダイナミックに変化しており, 情報を伝え る話し方としてよりふさわしいと判断されたためだと 考えられる.

発話系列特徵の有無に関する比較では，発話系列特 徵を加えたときの方が良い結果が得られた。発話系列 特徵を加えることによって, 発話系列全体として核が 際立つようなメリハリのある話し方を実現できたため だと考えられる。

\section{8. 評価実験 3: 理解度に及ぼす影響の評価}

7 章で説明した 3 つの操作（間（ま）の調整，段落発 話データの使用, 発話系列特徵の追加）を加えること で，ニュースの理解度にどの程度影響を及ぼすか評価 を行った。

\section{$8 \cdot 1$ 実 験 概 要}

10 個のニューストピックについて，7 章で説明した 4 種類の音声（表 8）を合成し， 7 章で述べた $\mathrm{A}, \mathrm{B}, \mathrm{C}$ の3つのタスクについて評価を行った.

各タスク 10 人ずつ合計 30 人に対して実験を行った. 各タスクの評価では, 被験者ごとにタイプ $i(\in\{1,2,3\})$ の音声が 5 トピック, タイプ $i+1$ の音声が 5 トピック となるように配分し, ランダムな順序で実施した。1卜 ピックは 3 段落から 5 段落の発話系列から構成される.

実験では，被験者に対して 1 トピック音声が聴き終 わるごとに質問に回答させた。質問は 1 トピックにつ き核の内容に関する質問と核以外の内容に関する質問 を 1 問ずつ用意した。例えば，図 3 のようなニュース に対し，核の内容に関する質問として「信号を発してい た恒星は何座の近くにありますか」, 核以外の内容に関 する質問として「信号を観測したのはどこの国ですか」 のような質問を作成した。質問はなるべくニュースの 前半の内容から作成した。回答は記述式で，完全に正 解している場合を 1 点, 部分的に正解している場合を 0.5 点として採点を行った．例えば，フルネームを答え るべきところを名字のみが正解していた場合などは部 分点を与えた。被験者には「1つのトピックで音声を 聴いてよいのは一度だけ」「メモを取ってはならない」 「分からない場合は未記入でよい」ことを指示した。

\section{$8 \cdot 2$ 実 験 結 果}

各タスクについて正解率を算出した結果を表 9, 表 10, 表 11 に示す.

タスク A の結果（表 9）から，短く単調な間（ま）で 話すよりも適度な長さの間（ま）を入れて話す方が内 容が頭に入りやすいことが分かった.

タスク B の結果（表 10）から, 従来の 1 文単位の読 み上げ音声を用いて学習したモデルよりも，相手に伝 
表 9 【実験 3】タスク A : 間（ま）の調整の有無に関する比較

\begin{tabular}{c|c|c}
\hline \hline & 間（ま）の調整なし & 間（ま）の調整あり \\
\hline 正解率（全体） & 0.595 & 0.675 \\
\hline
\end{tabular}

表 10 【実験 3】タスク B : 単発話モデルと段落発話モデルの比較

\begin{tabular}{l|c|c}
\hline \hline & 単発話モデル & 段落発話モデル \\
\hline 正解率 (全体) & 0.525 & 0.615 \\
\hline
\end{tabular}

表 11 【実験 3】タスク C : 発話系列特徵の有無に関する比較

\begin{tabular}{l|c|c}
\hline \hline & 発話系列特徵なし & 発話系列特徵あり \\
\hline 正解率（核） & 0.770 & 0.780 \\
\hline 正解率（核以外） & 0.660 & 0.640 \\
\hline 正解率（全体） & 0.715 & 0.710 \\
\hline
\end{tabular}

えることを強く意識させたうえで段落単位で発話させ た音声を用いて学習したモデルの方が頭に入りやすい ことが分かった。

タスク Cにおいては, 発話系列特徴の利用によって, それを利用しない場合よりも正解率が向上することを 期待したが，ほとんど差が見られなかった（表 11）。 ま た，発話系列特徵なしの合成音声では核の内容に関す る質問の正解率と核以外の内容に関する質問の正解率 の差が小さく，発話系列特徵ありの合成音声ではこの 差が大きくなることも期待したが，有意な差は見られ なかった。

7 章の実験結果（図 16）も踏まえると，発話系列特 徵を利用することで，情報を伝える話し方に関する主 観的な評価は改善するものの，今回のような実験設定 では，理解度に関する客観的な評価までは改善できな いことが分かった。

\section{9. 評価実験 4: 質問しやすさに関する評価}

7 章の評価は，受け身で聴いたときの評価であった。 そのため，特に間（ま）の評価において，ただ聴くだ けにしては長い間（ま）も存在しており，間（ま）の 有効性が十分に評価できていない.

間 (ま) の役割には咀嚼・理解の促進の他に, フィード バックの誘発がある.インタラクティブなやり取りを 通して情報を伝える会話システムにおいて, ユーザーが フィードバックを示しやすい間 (ま) の取り方になって いることが重要である。そこで，本節では，ユーザーが 示すフィードバックの中でも特に情報伝達効率（EoIT; Efficiency of Information Transfer） [高津 18a] に寄与す る質問を対象に，間（ま）の調整の有無が質問のしや すさにどのような影響を及ぼすか評価を行った。

\section{1 実 験 概 要}

音声合成モデルには発話系列特徵を加えて学習した 段落発話モデルを使用した。このモデルによって生成
表 12 質問しやすさの評価実験で用いたシナリオの例（太線は発話 文の区切り，細線は発話節の区切り)

\begin{tabular}{|c|c|}
\hline 発話節の内容 & 吕ーズ長（秒） \\
\hline $\begin{array}{l}\text { はやぶさ } 2 \text { を搭載したロケットの打ち上げが } \\
\text { 成功したらしいよ }\end{array}$ & 1.95 \\
\hline $\begin{array}{l}\text { はやぶさ } 2 \text { のミッションはある小惑星からサ } \\
\text { ンプルを採取してくることなんだって }\end{array}$ & 2.13 \\
\hline 惑星に到着したら & 0.14 \\
\hline 赤外線カメラとかを使って & 0.35 \\
\hline 表面の状態を観測したり & 0.48 \\
\hline HvMpX を惑星にぶつけて & 0.82 \\
\hline $\begin{array}{l}\text { その衝撃でできたクレーターを観測したりす } \\
\text { るんだって }\end{array}$ & 2.37 \\
\hline 到着は 2018 年で & 0.24 \\
\hline 18 ケ月間のミッションを経て & 0.53 \\
\hline 2020 年にサンプルを地球に持ち帰るんだって & \\
\hline
\end{tabular}

された合成音声に対して提案手法によって間（ま）の 調整を行ったシナリオと, $4 \cdot 1$ 節で収録した音声デー タにおける核から核へ移行する際の平均時間に基づい て発話節間のポーズ長を 0.5 秒に固定した，間（ま）の 調整なしのシナリオをそれぞれ 2 トピックずつ合計 4 トピック用意し，被験者 16 人に対して会話させた。

4 つのニューストピックには, アルファベット数文字 からなる未知の単語が含まれている，未知語はニュー ス記事中の略語（e.g. “HMX”）の文字の間にアルファ ベットを挿入することで作成した (e.g. "HvMpX"). 評 価実験で使用したシナリオの例を表 12 に示す。図 1 の シナリオ生成部で主計画を作成する処理（要約と口語 化）は人手で行った. 表 12 の “HvMpX”が未知語であ り，未知語を含む発話節の終了地点が質問がくると予 想される箇所である (表 12 の「…ぶつけて」の後). 表 12 のポーズ長は提案手法で推定した結果であり，間 （ま）の調整なしの場合はすべて 0.5 秒とした．なお， 4 つのトピックの質問想定箇所における推定結果のポー ズ長はすべて 0.5 秒よりも長い.

被験者には，知らない単語があった際には「何それ」 と質問するように指示した。1トピックにつき間（ま） の調整ありの会話が 8 人, 間 (ま) の調整なしの会話が 8 人となるように配分し, 被験者ごとに 4 つのトピック をランダムな順序で実施した。ただし，間（ま）の調整 ありの 2 トピックと間（ま）の調整なしの 2 トピック が前半と後半に分かれるような順番で実施した。実験 後のアンケートでは, 前半 2 つの会話と後半 2 つの会 話でどちらが質問しやすかったかについて回答させた。

\section{$9 \cdot 2$ 実 験 結 果}

実験後のアンケートで得られた質問しやすさに関す る評価結果を図 17 に示す。この結果から, 約 7 割の被 験者は，内容に応じて間（ま）の長さを調節する話し 方の方が，一定の短い間（ま）で淡々と発話する話し 方よりも質問しやすいと評価したことが分かる. 
ロ段落発話モデル(間(ま)の調整なし, 発話系列特徵あり) ロ段落発話モデル(間(ま)の調整あり, 発話系列特徵あり)

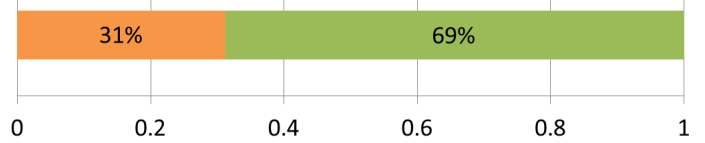

図 17 質問しやすさに関する評価結果

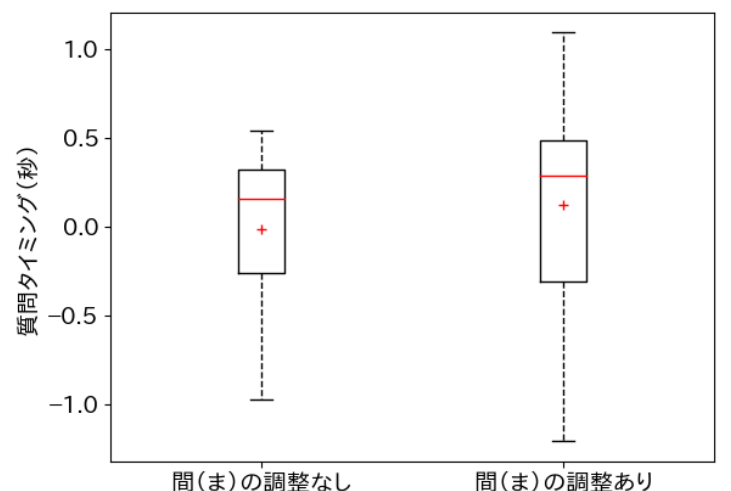

図 18 質問想定箇所を基準としたときの質問タイミングの分布

表 13 質問想定箇所を基準としたときの質問するまでの平均時間 (秒)

\begin{tabular}{c|c}
\hline \hline 間（ま）の調整なし & 間（ま）の調整あり \\
\hline-0.016 & 0.123 \\
\hline
\end{tabular}

未知語を含屯発話節の発話終了時刻を基準として何 秒後に質問があったか, 間（ま）の調整なしの会話時 と間（ま）の調整ありの会話時のそれぞれについて箱 ひげ図で表したものを図 18 に示す．また，質問するま での平均時間を算出した結果を表 13 に示す.ここで, 質問想定箇所よりも前で質問が来た場合の時刻は負の 值としている．また，「え、何それ」や「ん、何それ」 のような質問は「え」や「ん」のタイミングを質問のタ イミングとした。これらの結果から，間（ま）の調整 を行ったときの方が質問するタイミングが平均的に遅 いことが分かる。これは, 間（ま）の調整なしの会話 の方が話すテンポが早いため, システムのテンポに引 きずられてユーザーの質問するタイミングが早くなっ たためだと考えられる.

質問を条件ごとに分類したときの事例数を図 19 に 示す. 未知語について質問した事例数は間（ま）の調 整なしの方が多かったものの, 0.5 秒以上後で質問した 事例数は間（ま）の調整ありの方が多かった. 間（ま） の調整なしの会話は単調なテンポで発話が行われるた め, システムが次に発話するタイミングを予測しやす い. 今回はその間 (ま) が 0.5 秒であったため, 間 (ま) の調整なしの会話では 0 秒以上 0.5 秒未満で質問した ものの数が多かったと考えられる。一方, 間（ま）の調 整ありの会話は内容に応じて間（ま）の長さが変化す

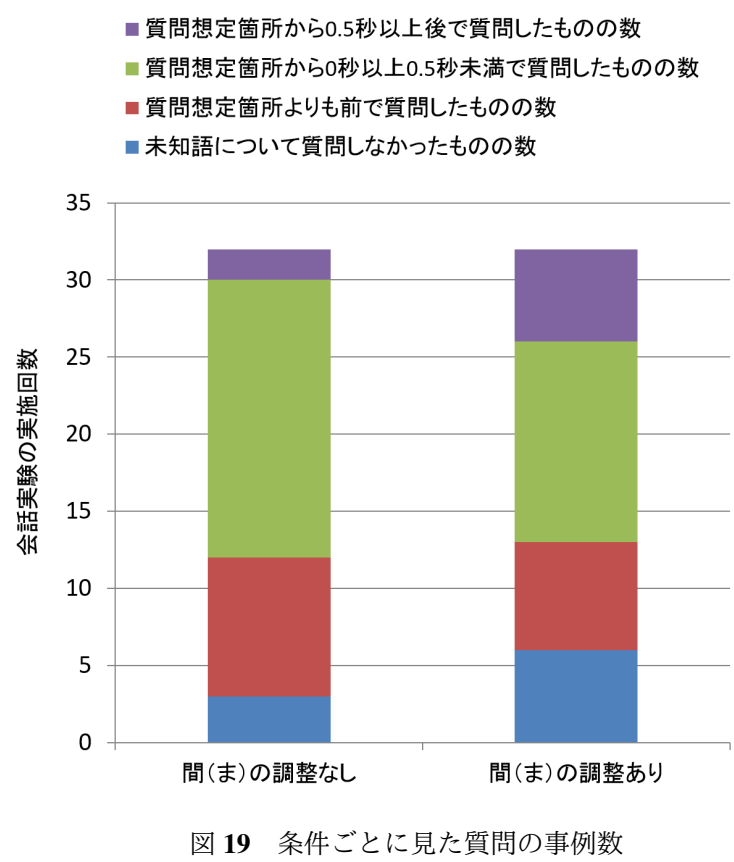

る.中には 0.5 秒よりも短いものもあるが，発話文の 区切りや質問が予想される箇所では適度に長い間（ま） が挿入される。このようなメリハリのある話し方をす ることで, 被験者はシステムのテンポに惑わされずに 自分のタイミングで質問でき，その結果，少し間（ま） をおいたタイミングで質問が行われたと考えられる.

図 17 の結果も踏まえると，内容に応じて間（ま）の 調節を行う話し方の方が，短い単調な間（ま）で発話 する話し方よりも質問しやすい間（ま）を実現できた と考えられる。

\section{0.おわりに}

ニュースのようなまとまった量の情報を伝える会話 システムにおいて, 談話構造上の発話の役割に応じた メリハリのある話し方を可能とする音声合成システム を開発した。

書き言葉と話し言葉の違いに留意して, ニュース記 事をもとに発話原稿を作成し, 音声収録を行い, 発話 の位置や役割を考慮した DNN 音声合成モデルと，文節 間・発話文間のポーズ長を推定するモデルを提案した。

提案した間（ま）の推定モデルによって，人の作る 間（ま）に近い適切な間（ま）を推定でき，挿入すべき 間（ま）の長さを一定の短い間（ま）で淡々と発話す る話し方よりも，聴きやすく頭に入りやすく，さらに 質問しやすい話し方を実現できることが確認できた。

また, 従来の 1 文単位の読み上げ音声で学習したモ デルよりも，情報伝達を意識させ段落単位で発話させ た音声を用いて学習したモデルの方が，情報伝達のた めの発話としてふさわしいと感じるとともに, 内容理 解の面においても優れていることが分かった. 
さらに，発話の段落における位置や談話構造上の役 割を補助情報に用いて合成することにより，情報伝達 にふさわしい聴きやすい話し方になることが確認でき た。しかしながら，その効果が，理解度を向上させると ころまでには至らなかった。今回の実験条件では，被 験者は集中して音声を聴くことができたため，多少メ リハリの弱い話し方であっても十分に内容を理解する ことができたと考えられる，今後は，運転しながら，料 理しながらといった多重タスクの条件下で，理解度テ ストを実施し，求められるメリハリの水準を上げたと きの発話系列特徵の導入効果について検討したい.

今回の研究では，システムが主体的に情報伝達を行 うという状況に焦点を当てて検討を行った。そのため, ユーザーはうなずきながらシステムの話を聞いている ことを仮定し，声優が演技して発話した音声を分析対 象とした。しかしながら，より活性化された会話にお いて，システム発話のリズムは，ユーザー発話のリズ ムに影響を受けることが予想される。これらの相互作 用をモデル化する立場に立つならば，より統制の少な い会話環境で収集した音声の分析を進めることも重要 である。

\section{$\diamond$ 参 考 文 献 $\diamond$}

[Adigwe 18] Adigwe, A., Tits, N., Haddad, K.E., Ostadabbas, S., and Dutoit, T.: The emotional voices database: Towards controlling the emotion dimension in voice generation systems, in Proceedings of the 6th International Conference on Statistical Language and Speech Processing (2018)

[Burkhardt 05] Burkhardt, F., Paeschke, A., Rolfes, M., Sendlmeier, W.F., and Weiss, B.: A database of German emotional speech, in Proceedings of the 9th European Conference on Speech Communication and Technology, pp. 1517-1520 (2005)

[Chafe 94] Chafe, W.: Discourse, consciousness, and time, University Of Chicago, Vol. 2 (1994)

[Fukuoka 17] Fukuoka, I., Iwata, K., and Kobayashi, T.: Prosody control of utterance sequence for information delivering, in Proceedings of the 18th Annual Conference of the International Speech Communication Association, pp. 774-778 (2017)

[後藤 16] 後藤功雄, 田中英輝: 日本語連体修飾節の抽出による文 分割の可否判断に適した基準の提案, 言語処理学会 第 22 回年次 大会 発表論文集, pp. 1057-1060 (2016)

[畠 87] 畠弘巳: 話しことばの特徴 - 圥長性をめぐって -, 国文学解 釈と鑑賞, Vol. 52, No. 7, pp. 22-34 (1987)

[Hirschberg 96] Hirschberg, J. and Nakatani, C.H.: A prosodic analysis of discourse segments in direction-giving monologues, in Proceedings of the 34th Annual Meeting on Association for Computational Linguistics, pp. 286-293 (1996)

[北条 16a] 北条伸克, 井島勇祐, 杉山弘晃: 対話行為情報を表現可 能な音声合成の検討, 人工知能学会 第 30 回全国大会 論文集, 2O4-OS-23a-4, pp. 1-4 (2016)

[Hojo 16b] Hojo, N., Ijima, Y., and Mizuno, H.: An investigation of DNN-based speech synthesis using speaker codes, in Proceedings of the 17th Annual Conference of the International Speech Communication Association, pp. 2278-2282 (2016)

[Hojo 18] Hojo, N., Ijima, Y., and Mizuno, H.: DNN-based speech synthesis using speaker codes, IEICE Transactions on Information and Systems, Vol. E101D, No. 2, pp. $462-472$ (2018)

[Inoue 17] Inoue, K., Hara, S., Abe, M., Hojo, N., and Ijima, Y.: An investigation to transplant emotional expressions in DNN-based TTS synthesis, in Proceedings of the 9th Asia-Pacific Signal and Infor- mation Processing Association Annual Summit and Conference, pp. 1253-1258 (2017)

[岩田 94] 岩田和彦: 文章朗読音声における韻律的特徵の分析, 日 本音響学会研究発表会講演論文集, pp. 285-286 (1994)

[Iwata 11] Iwata, K. and Kobayashi, T.: Conversational speech synthesis system with communication situation dependent HMMs, in Proceedings of the Paralinguistic Information and its Integration in Spoken Dialogue Systems Workshop, pp. 113-123 (2011)

[鴨井 11] 鴨井一人, 山本知仁, 三宅美博: 文章発話におけるポーズ 長とその前後の発話長の作用関係, ヒューマンインタフェースシ ンポジウム 2011 論文集, pp. 357-364 (2011)

[Kawahara 06] Kawahara, H.: STRAIGHT, exploitation of the other aspect of VOCODER: Perceptually isomorphic decomposition of speech sounds, Acoustical Science and Technology, Vol. 27, No. 6, pp. 349-353 (2006)

[小林 14] 小林哲則, 岩田和彦: 会話向け音声合成システム, 電子情 報通信学会技術研究報告, Vol. 114, No. 303, pp. 19-24 (2014)

[Koiso 97] Koiso, H., Shimojima, A., and Katagiri, Y.: Informational potentials of dynamic speech rate in dialogue, in Proceedings of the 19th Annual Conference of the Cognitive Science Society, pp. 394399 (1997)

[駒谷 03] 駒谷和範, 上野晋一, 河原達也, 奥乃博: ユーザモデルを 導入したバス運行情報案内システムの実験的評価, 情報処理学会 研究報告, Vol. 2003, No. 75(SLP-47), pp. 59-64 (2003)

[Luong 17] Luong, H.T., Takaki, S., Henter, G.E., and Yamagishi, J.: Adapting and controlling DNN-based speech synthesis using input codes, in Proceedings of the 42nd IEEE International Conference on Acoustics, Speech and Signal Processing, pp. 1905-1909 (2017)

[Malisz 17] Malisz, Z., Berthelsen, H., Beskow, J., and Gustafson, J.: Controlling prominence realisation in parametric DNN-based speech synthesis, in Proceedings of the 18th Annual Conference of the International Speech Communication Association, pp. 1079-1083 (2017)

[Mann 88] Mann, W.C. and Thompson, S.A.: Rhetorical structure theory: Toward a functional theory of text organization, TextInterdisciplinary Journal for the Study of Discourse, Vol. 8, No. 3, pp. 243-281 (1988)

[Montano 13] Montano, R., Alias, F., and Ferrer, J.: Prosodic analysis of storytelling discourse modes and narrative situations oriented to text-to-speech synthesis, in Proceedings of the 8th ISCA Speech Synthesis Workshop, pp. 171-176 (2013)

[西野 12] 西野浩輝: 仕事ができる人の 5 日で身につく「伝える技 術」, 東洋経済新報社 (2012)

[のざき 18] のざききいこ: 声と言葉のプロが教える伝わる話し方, 秀和システム (2018)

[小野 18] 小野喜己: ニューラルネットワークを用いたアクセント 句境界及びアクセント核推定, 早稲田大学 2017 年度卒業論文, 第 2 章ニューラルネットワークを用いたアクセント推定, pp. 11-16 (2018)

[Ramli 16] Ramli, I., Seman, N., Ardi, N., and Jamil, N.: Rule-based storytelling text-to-speech (TTS) synthesis, in Proceedings of the 3rd International Conference on Mechanics and Mechatronics Research, pp 1-6 (2016)

[Ramli 17] Ramli, I., Jamil, N., Seman, N., and Ardi, N.: The first Malay language storytelling text-to-speech (TTS) corpus for humanoid robot storytellers, Journal of Fundamental and Applied Sciences, Vol. 9, No. 4S, pp. 340-358 (2017)

[Ronanki 16] Ronanki, S., Wu, Z., Watts, O., and King, S.: A demonstration of the Merlin open source neural network speech synthesis system, in Proceedings of the 9th ISCA Speech Synthesis Workshop, pp. 124-124 (2016)

[Sarkar 14] Sarkar, P., Haque, A., Dutta, A., Reddy, G., Harikrishna, M., Dhara, P., Verma, R., Narendra, P., Sunil, B., Yadav, J., and Rao, K.S.: Designing prosody rule-set for converting neutral TTS speech to storytelling style speech for indian languages: Bengali, Hindi and Telugu, in Proceedings of the IEEE 7th International Conference on Contemporary Computing, pp. 473-477 (2014)

[Sarkar 15a] Sarkar, P. and Rao, K.S.: Modeling pauses for synthesis of storytelling style speech using unsupervised word features, Procedia Computer Science, Vol. 58, pp. 42-49 (2015)

[Sarkar 15b] Sarkar, P. and Rao, K.S.: Data-driven pause prediction for speech synthesis in storytelling style speech, in Proceedings of 
the 21 st National Conference on Communications, pp. 1-5 (2015)

[Sarkar 15c] Sarkar, P. and Rao, K.S.: Data-driven pause prediction for synthesis of storytelling style speech based on discourse modes, 2015 IEEE International Conference on Electronics, Computing and Communication Technologies, pp. 1-5 (2015)

[Seneff 00] Seneff, S. and Polifroni, J.: Dialogue management in the mercury flight reservation system, in Proceedings of the 2000 ANLP/NAACL Workshop on Conversational Systems, Vol. 3, pp. 11$16(2000)$

[Sugiura 14] Sugiura, K., Shiga, Y., Kawai, H., Misu, T., and Hori, C.: Non-monologue HMM-based speech synthesis for service robots: A cloud robotics approach, IEEE International Conference on Robotics and Automation, pp. 2237-2242 (2014)

[高津 18a] 高津弘明, 福岡維新, 藤江真也, 林良彦, 小林哲則: 意図 性の異なる多様な情報行動を可能とする音声対話システム, 人工 知能学会論文誌, Vol. 33, No. 1, pp. 1-24 (2018)

[高津 18b] 高津弘明, 横山勝矢, 本田裕, 藤江真也, 林良彦, 小林哲 則: 会話によるニュース記事伝達のための間の調整, 言語処理学 会第 24 回年次大会 発表論文集, pp. 212-215 (2018)

[武田 91a] 武田昌一, 市川喜: 日本語文音声におけるプロミネンス の韻律的特徵の解析, 日本音響学会誌, Vol. 47, No. 6, pp. 386-396 (1991)

[武田 91b] 武田昌一, 市川喜: 日本語文音声のプロミネンス生成 規則の作成と評価, 日本音響学会誌, Vol. 47, No. 6, pp. 397-404 (1991)

[Theune 06] Theune, M., Meijs, K., Heylen, D., and Ordelman, R.: Generating expressive speech for storytelling applications, IEEE Transactions on Audio, Speech, and Language Processing, Vol. 14, No. 4, pp. 1137-1144 (2006)

[Traum 15] Traum, D., Georgila, K., Artstein, R., and Leuski, A.: Evaluating spoken dialogue processing for time-offset interaction, in Proceedings of the 16th Annual SIGdial Meeting on Discourse and Dialogue, pp. 199-208 (2015)

[Verma 15] Verma, R., Sarkar, P., and Rao, K.S.:Conversion of neutral speech to storytelling style speech, in Proceedings of the 8th International Conference on Advances in Pattern Recognition, pp. 1-6 (2015)

[Wu 15] Wu, Z., Swietojanski, P., Veaux, C., Renals, S., and King, S.: A study of speaker adaptation for DNN-based speech synthesis, in Proceedings of the 16th Annual Conference of the International Speech Communication Association, pp. 879-883 (2015)

[Wu 16] Wu, Z., Watts, O., and King, S.: Merlin: An open source neural network speech synthesis system, in Proceedings of the 9th ISCA Speech Synthesis Workshop, pp. 218-223 (2016)

[Yoshino 15] Yoshino, K. and Kawahara, T.: News navigation system based on proactive dialogue strategy, in Proceedings of the International Workshop Series on Spoken Dialogue Systems Technology, pp. 1-12 (2015)

[Zen 13] Zen, H., Senior, A., and Schuster, M.: Statistical parametric speech synthesis using deep neural networks, in Proceedings of the 2013 IEEE International Conference on Acoustics Speech and Signal Processing, pp. $7962-7966$ (2013)

[Zhao 16] Zhao, Y., Saito, D., and Minematsu, N.: Speaker representations for speaker adaptation in multiple speakers' BLSTM-RNNbased speech synthesis, in Proceedings of the 17th Annual Conference of the International Speech Communication Association, pp. 2268-2272 (2016)

〔担当委員 : 岡田 将吾〕

2018 年 6 月 27 日 受理

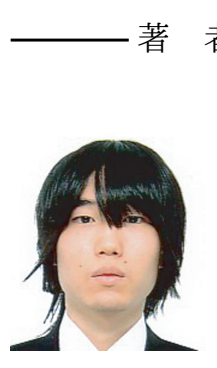

\section{者 紹 介}

高津 弘明 (学生会員)

2014 年早稲田大学基幹理工学部情報理工学科卒業. 2016 年同大学基幹理工学研究科情報理工 · 情報通信専攻博士 前期課程修了. 現在, 同専攻博士後期課程在学中. 自然 言語処理・音声対話システムに関する研究に従事．言語 処理学会会員.

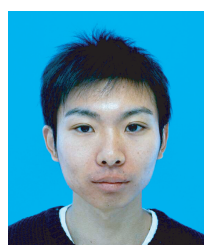

福岡 維新

2015 年早稲田大学基幹理工学部情報理工学科卒業. 2017 年同大学基幹理工学研究科情報理工・情報通信専攻博士 前期課程修了. 2017 年 4 月より IT 企業勤務。在学中 は音声対話システム, 音声合成に関する研究に従事. 音 響学会会員。

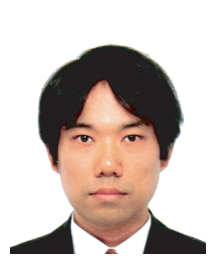

藤江 真也（正会員）

2004 年早稲田大学大学院理工学研究科博士課程単位取 得退学. 早稲田大学理工学部助手, 同大学理工学総合研 究所客員講師, 同大学高等研究所助教, アズビル株式会 社勤務を経て，2014 年より千葉工業大学先進工学部未来 ロボティクス学科准教授. 博士 (工学)。専門は音声対話 システム・会話ロボット・マルチモーダル情報処理. 日 本音響学会, 情報処理学会, 電子情報通信学会, 日本感 性工学会各会員。

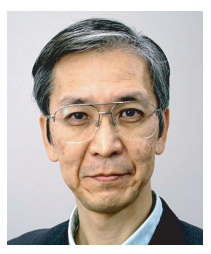

岩田 和彦

1986 年早稲田大学大学院理工学研究科修士課程修了. 1986 2007 年日本電気株式会社勤務。この間，音声合 成技術の研究開発，音声認識応答装置の製品開発，音声 インタフェースを有する応用システムの実用化などに従 事. 2007 年より早稲田大学勤務，ロボットのための対話 音声合成システムの研究開発に従事. 1995 年日本音響 学会技術開発賞受賞. 電子情報通信学会, 日本音響学会 各会員.

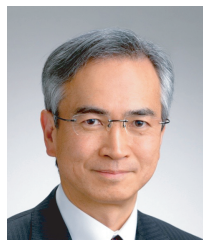

小林 哲則 （正会員）

1985 年早稲田大学大学院理工学研究科博士課程修了. 工 学博士. 同年, 法政大学工学部電気工学科専任講師. 同 助教授, 早稲田大学理工学部電気電子情報工学科助教授 を経て，1997 年同教授．現在，同大学理工学術院基幹理 工学部情報通信学科教授. MIT, Laboratory for Computer Science, ATR 音声言語通信研究所, NHK 放送技術研究 所などの客員研究員を歴任. 音声認識, 画像認識, 会話 システム, IoT などの研究に興味を持つ. 